\title{
Baseline hypocapnia is associated with intubation in COVID-19 diagnosed patients
}

Athanasios Gounidis ${ }^{2}$, Alexandros P. Evangeliou², Christina Kloura², Evangelia Manganari $^{2}$, Christiana Parisi ${ }^{2}$, Michalis Kourtidis ${ }^{2}$, Georgios Kotronis ${ }^{2}$, Martha Apostolopoulou $^{2}$, Fani Apostolidou-Kiouti ${ }^{1}$

${ }^{1}$ Biomedical Statistics Unit, Medical Faculty, Aristotle University of Thessaloniki, Greece

${ }^{2}$ Department of Internal Medicine, Agios Pavlos General Hospital of Thessaloniki, Greece

\section{Corresponding Author}

Fani Apostolidou Kiouti

Biomedical Statistics Unit, Medical Faculty, Aristotle University of Thessaloniki, Greece

Tel.: +30 2313304740

e-mail: faniapk@gmail.com

\section{ABSTRACT}

\section{Introduction}

Hypocapnia may be one of the several factors predefining the need for intubation of patients needing hospitalization for COVID-19 pneumonia.

\section{Methods}

A retrospective evaluation of patient files hospitalized for COVID-19 pneumonia from October 2020 until January 2021. Univariate and multivariate regression was used, as well as a multinomial regression to account for multiple endpoints (discharge, intubation, death).

\section{Results}


Hypocapnia was strongly associated with intubation (OR: $0.86,95 \% \mathrm{Cl}: 0.76,0.97$ ). Additionally, last pCO2 (OR: 1.08, 95\% Cl: 1.01, 1.16), baseline FiO2 (OR: 1.05, 95\% Cl: $1.03,1.07)$ as well as last FiO2 (OR: 1.21, 95\% Cl: 1.11, 1.46), total severity score on admission (OR: 1.18, 95\% Cl: 1.03, 1.37) and last pO2 (OR: 0.89, 95\% Cl: $0.85,0.92)$ were found to have a significant impact on intubation. Incorporation of deceased patients withheld the negative association with pCO2 levels (OR: 0.88 , 95\% Cl: 0.78, 0.98).

\section{Conclusion}

The dissociation between respiratory failure and a clinically comfortable patient is partly due to decreased carbon dioxide levels and clinicians should bare it in mind when handling patients with COVID-19 pneumonia. Hypocapnia seems to be a determinant factor of intubation in patients with COVID-19 pneumonia in this study.

Keywords: COVID-19;Hypocapnia;Intubation

\section{INTRODUCTION}

The severe acute respiratory syndrome (Sars-CoV-2) pneumonia was first diagnosed in December of 2019 in China and quickly grew to a pandemic with significant impact on health systems worldwide. A wide spectrum of clinical severity has been reported, ranging from asymptomatic to critically ill patients ${ }^{1,2}$. Recently published systematic reviews reported that the most frequent symptoms of these patients are fever and cough followed by shortness of breath and myalgia ${ }^{3,4}$. A major 
clinical characteristic, complicating patient care, is the paradoxical lack of dyspnea despite extremely low hemoglobin saturation and partial pressure of oxygen $\left(\mathrm{pO}_{2}\right)$ in arterial blood; two thirds of coronavirus disease 2019 (COVID-19) hospitalized patients had not complained of shortness of breath on admission, despite present signs of pneumonia in computed tomography chest scan ${ }^{5,6}$ and low $\mathrm{pO}_{2}$ in arterial blood gases (ABGs). Hypoxemia without respiratory distress has previously been associated with poor outcome in patients developing acute respiratory distress syndrome (ARDS), with the majority of patients being intubated or died ${ }^{7}$. The pathophysiological mechanism for hypoxia upon admission has yet to be determined, while association of hypoxia with the thrombosis of pulmonary vessels has also been described ${ }^{8}$. This association could be due to several mechanisms including ventilation/ perfusion (V/Q) mismatch, thrombotic events, SARS-CoV-2 specific effect on chemoreceptors, altered diffusion capacity or loss of vasoadaptive mechanisms ${ }^{9}$.

Happy or silent hypoxia seems to have a significant pathophysiological role in the clinical presentation of patients with COVID-19 pneumonia ${ }^{10}$; a state in which low pO2 along with normal or low partial pressure of carbon dioxide ( $\mathrm{pCO} 2)$ and normal or increased alveolar ventilation are not perceived as respiratory discomfort. Since hypocapnia has already been related with poorer outcomes in patients requiring invasive mechanical ventilation (IMV) ${ }^{11,12}$, this study was conducted to investigate a possible association between carbon dioxide levels in the early stages of disease and progression to intubation.

\section{DESIGN - METHODS}




\section{Study design}

This is retrospective cohort study which was conducted in our centre between October 2020 and January 2021. It is a referral hospital assigned to hospitalize patients undergoing reallocation from other centres due to full occupancy. All the medical reports from patients were collected and data from medical records were further analyzed.

\section{Participants}

Consecutive patients older than 18 years of age, with or without previously diagnosed pulmonary disease, irrespective of smoking status, race or gender, diagnosed with COVID-19 pneumonia confirmed with nasopharyngeal swab test (polymerase chain reaction) requiring hospitalization. Patients were followed up until intubation or exit. Patients that died in-hospital were excluded from primary analysis but were included in a multinomial model. Recorded data included days since diagnosis and symptom onset, type of oxygen delivery including non-invasive mechanical ventilation (NIMV), time from hospitalization onset to intubation or hospital discharge, radiological findings, pharmacological interventions (previous and disease related) ABGs analyses on admission and before intubation or hospital discharge. All arterial blood gases were analyzed on the same analyzer (ABL800

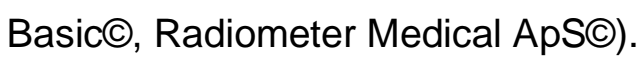

\section{Outcomes}

This study aimed to assess the relationship between hypocapnia (defined as pCO2 lower than $35 \mathrm{mmHg}$ ) upon admission and need for IMV in patients with COVID-19 pneumonia. Secondary outcomes included the impact of pCO2 on the composite 
outcome of intubation or mortality, the impact of NIMV on intubation and the combined effect of days since symptom onset and pCO2 upon admission on the incidence of intubation.

\section{Study size}

Based on Riley et al. ${ }^{13}$, assuming a prevalence of $3.2 \%$ for intubation based on upto-date published data $^{14}$ and an R-squared of $18 \%$ for a model evaluating simultaneously up to three parameters (package pmsampsize for $R, v .4 .0 .2$ ) a sample of 216 patients is required to draw safe conclusion with at least 7 events.

\section{Statistical methods}

Appropriate descriptives were derived for all recorded variables. Logistic regression was used to assess the impact of pCO2 on the incidence of intubation. The predefined parameters (as defined in the study protocol) were assessed with univariate analysis: days since symptom onset and diagnosis, radiological severity, pO2 before intubation, type of NIMV prior to intubation. Odds ratios (OR) with 95\% confidence intervals $(\mathrm{Cl})$ were calculated and reported along with the corresponding degrees of freedom. Taking into consideration sample characteristics, clinical significance and the univariate regression results, a multivariate model was built. A multinomial logistic regression model was fitted to incorporate data from deceased patients who were not intubated ${ }^{15}$. Data were recorded in an Access database. Analyses were run in R, v. 4.0.2. Missing data were not imputed, and incomplete cases were excluded from the respective analyses. No loss to follow-up occurred.

\section{RESULTS}




\section{Characteristics of study population}

Between October 2020 and January 2021, a total of 306 patients were hospitalized for COVID-19 pneumonia of variable severity. A total of 274 were included in the primary analysis (Fig.1); $6.9 \%(\mathrm{n}=19 / 274)$ of them were intubated and $93 \%$ $(n=255 / 274)$ were discharged. Baseline characteristics of the two groups are depicted in Table 1. No systematic differences were found for gender, age, history of pulmonary disease, prior anticoagulant therapy or comorbidities. Only $21 \%(n=4 / 19)$ of the intubated patients did not receive NIMV prior to intubation; all of them were deteriorating rapidly and immediate intubation and IMV was decided. Median time since symptom onset was 4 days (interquartile range-IQR: 6 ) in the discharge group and 3 days (IQR: 6 ) in the intubation group; median time between admission and intubation was 4 days (IQR: 6). Peak fraction of inspired oxygen (FiO2) needs was observed within the first three days from admission in $73.2 \%(n=201 / 274)$ of all patients.

There was a statistically significant difference in baseline $\mathrm{pCO} 2$ in ABGs sample between the two groups; pCO2 was $33.6 \mathrm{mmHg}$ (median) in the discharge group (IQR: 5.7) and $29.7 \mathrm{mmHg}$ (IQR: 5.0) on the intubation group (Wilcoxon rank-sum test p.value $=0.003)$. Admission ABGs demonstrated a significant difference on $\mathrm{pO} 2$ and FiO2: median pO2 was $86 \mathrm{mmHg}$ (IQR: 34 ) in the discharge group and $69 \mathrm{mmHg}$ (IQR: 37) on the intubation group (Wilcoxon rank-sum test p.value $=0.020$ ) Admission FiO2 needs were 21\% (IQR: 11) in the discharge group and 44\% (IQR: 59 ) in the intubation group (Wilcoxon rank-sum test p.value $=0.003$ ). Follow-up ABGs analysis showed a similar trend for $\mathrm{pO} 2$ and $\mathrm{FiO} 2$, as median $\mathrm{pO} 2$ was $86 \mathrm{mmHg}$ (IQR: 22) in the discharge group and $52 \mathrm{mmHg}$ (IQR: 17) on the intubation 
group (Wilcoxon rank-sum test p.value < 0.001). Follow up FiO2 needs were $21 \%$ (IQR: 0) in the discharge group and 95\% (IQR: 5) in the intubation group (Wilcoxon rank-sum test p.value $<0.001)$. There was no significant difference in follow up pCO2 (median 34.4mmHg (IQR: 5.9) in the discharge group and 32.2mmHg (IQR: 12.6) in the intubation group, Wilcoxon rank-sum test p.value $=0.8$ ). There was no difference in total severity score between groups; however, no formal assessment for agreement was undertaken in the presented setting. Values of baseline measurements of ABGs analyses are presented in Table 2.

Univariate analysis with logistic regression on the incidence of intubation is shown in Table 3. There was no statistically significant effect on the odds for intubation with respect to gender (OR: 1.64, 95\% Cl: 0.63, 4.80); age (OR: 1.03, 95\% Cl: 0.99, 1.06); history of pulmonary disease (OR: $2.58,95 \% \mathrm{Cl}: 0.79,7.28$ ); days since symptom onset (OR: 0.92, 95\% Cl: 0.78, 1.05); use of NIMV (CPAP vs BiPAP: 1.00, 95\% Cl: 0.05, 29.8, HFNC vs BiPAP OR: $2.25,95 \% \mathrm{Cl}: 0.21,25.2)$ or time elapsed (in days) from symptom onset to the first available ABG sample (OR: $0.95,95 \% \mathrm{Cl}$ : 0.89, 0.99). Baseline pO2 demonstrated borderline effect (OR: 0.98, 95\% Cl: 0.96, 1.00) with no useful clinical interpretation.

Parameters with statistically significant impact on the probability of intubation were baseline pCO2 measurement (OR: $0.86,95 \% \mathrm{Cl}: 0.76,0.97$ ) and last $\mathrm{pCO} 2$ measurement before intubation (OR: 1.08, 95\% Cl: 1.01, 1.16), baseline FiO2 (OR: 1.05, 95\% Cl: $1.03,1.07)$ as well as last FiO2 (OR: 1.21, 95\% Cl: 1.11, 1.46), total severity score on admission (OR: $1.18,95 \% \mathrm{Cl}: 1.03,1.37)$ and last pO2 (OR: 0.89 , $95 \% \mathrm{Cl}: 0.85,0.92)$. The primary outcome, the impact of baseline pCO2 on the odds 
for intubation, was found to increase by $16 \%$ for each unit of lower pCO2 on admission.

Taking into consideration sample characteristics, clinical significance and the univariate regression results, a multivariate model including baseline $\mathrm{pCO} 2$, days since symptom onset and baseline FiO2 was built (Table 3). The odds for intubation increased with the decrease of pCO2 by $19 \%$ given the time since symptom onset and baseline $\mathrm{FiO} 2$ needs. A multinomial logistic regression incorporating data including deceased patients (deceased prior to intubation) was fitted. Intubation is still negatively associated with pCO2 levels (OR: $0.88,95 \% \mathrm{Cl}: 0.78,0.98)$; mortality was not significantly related to the pCO2 (OR: $1.06,95 \% \mathrm{Cl}: 1.00,1.13$ ).

\section{DISCUSSION}

In the current study we aimed to explore the relationship between a respiratory parameter, $\mathrm{pCO} 2$, in COVID-19 pneumonia and the risk for intubation. Our findings suggest an increased risk for intubation in those patients presenting with reduced pCO2, augmented by higher oxygen requirements and the advance of time since symptom onset.

To our knowledge, no study aiming to investigate this relationship has yet been designed. It is acknowledged that oxygen saturation alone should reflect the respiratory performance in patients with COVID-19 pneumonia being evaluated for intubation $^{16}$. Published literature focuses on examining oxygen saturation and chemokines to determine those in danger for developing severe disease. However, from a physiological point of view, the evaluation of partial pressures measured in 
arterial blood is fundamental to associate prognosis and disease development and outcome.

Supporting evidence has been demonstrated in the literature published during the pandemic. Hypocapnia has been associated with worse outcome in a study by Brouqui et al. $^{16}$ in the context of asymptomatic hypoxia in a sample of COVID-19 patients undergoing at least one ABGs analysis. Although the population under study was diagnosed with more severe disease and had a longer time since symptom onset, hypoxia - hypocapnia syndrome was strongly associated with intensive care unit admission and death whereas hypoxia - hypercapnia was associated with positive outcomes. Another study by Turcato et al. ${ }^{17}$ demonstrated a negative correlation of $\mathrm{pCO} 2$ and the extent of pulmonary invasion in computed tomography as well as mortality. Both study groups propose the further exploration of pCO2 as a predictive parameter.

A recently published multicenter prospective cohort study described that patients with ARDS due to COVID-19 infection have more thrombotic events, as they mainly develop coagulopathy associated with poorer prognosis ${ }^{18}$ compared to patients with non-COVID-19 ARDS $^{19}$. The main thrombotic complication of these patients was pulmonary embolism causing severe hypoxia, hypocapnia and eventually respiratory distress ${ }^{19}$ while anticoagulant therapy might be associated with improved outcomes in patients with severe COVID-1920.

Several limitations are present in this observational study. The relatively small number of events, despite fulfilling the a priori power calculation to detect a 
difference, does not allow for generalization as a prognostic factor for intubation. This was a single centre study, with a limited number of cases; therefore caution is necessary when attempting to generalize the results. Future multicenter clinical trials included larger number of subjects are awaited to provide data about this prognostic factor. Another important constraint was the patient inflow, as the major proportion of patients were transferred from other hospitals, days after symptom onset and various stages of disease, having received various therapeutic agents. The baseline measurements of our study may not be homogenous with respect to days since symptom onset and treatment naïveté or nosocomial infection; in a larger sample this heterogeneity would yield a much more robust result. Another important constraint is the lack of evaluation for observer agreement for the radiological findings of chest computed tomography. Our data was not sufficient to run such analyses; as a result, this important parameter of disease severity could not be reliably assessed as a contributing factor.

Despite the limitations, there are several strengths in the current comparison. The most important is the inclusion of all admitted patients, regardless of comorbidities or previous respiratory disease. This allows for generalization of our main conclusion to a broader group of patients requiring hospitalization for COVID-19 pneumonia. Additionally, the use of a composite outcome allowed for inclusion of all patients, eliminating selection bias that would occur when excluding deceased patients. In the last year, numerous prognostic models for COVID-19 pneumonia have been published aiming to recognize as early as possible those patients who will require intensive care during their treatment. Most of them, despite reporting high $\mathrm{C}$ scores, are not externally validated or are deemed of high risk of bias, therefore their clinical 
medRxiv preprint doi: https://doi.org/10.1101/2021.11.19.21266581; this version posted November 21, 2021. The copyright holder for this preprint (which was not certified by peer review) is the author/funder, who has granted medRxiv a license to display the preprint in perpetuity. It is made available under a CC-BY-NC-ND 4.0 International license .

applicability is limited ${ }^{21}$. Adding $\mathrm{pCO} 2$ as a prognostic factor might be of clinical significance in these models and should be further investigated.

\section{CONCLUSION}

The dissociation between respiratory failure and a clinically comfortable patient is partly due to decreased carbon dioxide levels associated with COVID-19 pneumonia. Hypocapnia seems to be a determinant factor for intubation in patients with COVID19 pneumonia in this study.

\section{FUNDING}

There were no funding sources for the current study

\section{CONFLICT OF INTEREST}

All contributing authors have nothing to declare. 


\section{REFERENCES}

1. Chen N., M. Zhou, X. Dong, J. Qu, F. Gong, Y. Han, et al. Epidemiological and clinical characteristics of 99 cases of 2019 novel coronavirus pneumonia in Wuhan, China: a descriptive study. The lancet. 395(10223): 2020;507-13.

2. Huang C., Y. Wang, X. Li, L. Ren, J. Zhao, Y. Hu, et al. Clinical features of patients infected with 2019 novel coronavirus in Wuhan, China. The lancet. 395(10223): 2020;497-506.

3. Fu L., B. Wang, T. Yuan, X. Chen, Y. Ao, T. Fitzpatrick, et al. Clinical characteristics of coronavirus disease 2019 (COVID-19) in China: a systematic review and metaanalysis. Journal of Infection. 80(6): 2020;656-65.

4. Lovato A., C. De Filippis. Clinical presentation of COVID-19: a systematic review focusing on upper airway symptoms. Ear, Nose \& Throat Journal. 99(9): 2020;569-76.

5. Zhou F., T. Yu, R. Du, G. Fan, Y. Liu, Z. Liu, et al. Clinical course and risk factors for mortality of adult inpatients with COVID-19 in Wuhan, China: a retrospective cohort study. The lancet. 395(10229): 2020;1054-62.

6. Brouqui P., S. Amrane, M. Million, S. Cortaredona, P. Parola, J. C. Lagier, et al. Asymptomatic hypoxia in COVID-19 is associated with poor outcome. Int J Infect Dis. 102: 2021;233-8. 10.1016/j.ijid.2020.10.067

7. Xie J., N. Covassin, Z. Fan, P. Singh, W. Gao, G. Li, et al. Association Between Hypoxemia and Mortality in Patients With COVID-19. Mayo Clinic Proceedings. 95(6): 2020;1138-47. https://doi.org/10.1016/i.mayocp.2020.04.006

8. Nittari G., G. Pallotta, F. Amenta, S. K. Tayebati. Current pharmacological treatments for SARS-COV-2: A narrative review. Eur J Pharmacol. 882: 2020;173328. 10.1016/j.ejphar.2020.173328 
9. Osuchowski M. F., M. S. Winkler, T. Skirecki, S. Cajander, M. Shankar-Hari, G. Lachmann, et al. The COVID-19 puzzle: deciphering pathophysiology and phenotypes of a new disease entity. The Lancet Respiratory Medicine. 2021.

10. Ottestad W., S. Søvik. COVID-19 patients with respiratory failure: what can we learn from aviation medicine? British journal of anaesthesia. 125(3): 2020;e280-e1.

11. Laserna E., O. Sibila, P. R. Aguilar, E. M. Mortensen, A. Anzueto, J. M. Blanquer, et al. Hypocapnia and hypercapnia are predictors for ICU admission and mortality in hospitalized patients with community-acquired pneumonia. Chest. 142(5): 2012;1193-9.

12. Madotto F., E. Rezoagli, B. A. McNicholas, T. Pham, A. S. Slutsky, G. Bellani, et al. Patterns and impact of arterial CO2 management in patients with acute respiratory distress syndrome: insights from the LUNG SAFE study. Chest. 158(5): 2020;1967-82.

13. Riley R. D., K. I. Snell, J. Ensor, D. L. Burke, F. E. Harrell Jr, K. G. Moons, et al. Minimum sample size for developing a multivariable prediction model: PART II-binary and time-to-event outcomes. Statistics in medicine. 38(7): 2019;1276-96.

14. Meng L., H. Qiu, L. Wan, Y. Ai, Z. Xue, Q. Guo, et al. Intubation and Ventilation amid the COVID-19 Outbreak: Wuhan's Experience. Anesthesiology. 132(6): 2020;1317-32. 10.1097/aln.0000000000003296

15. Martin G. P., M. Sperrin, K. I. Snell, I. Buchan, R. D. Riley. Clinical prediction models to predict the risk of multiple binary outcomes: a comparison of approaches. Statistics in Medicine. 40(2): 2021;498-517.

16. Dhont S., E. Derom, E. Van Braeckel, P. Depuydt, B. N. Lambrecht. The pathophysiology of 'happy'hypoxemia in COVID-19. Respiratory research. 21(1): 2020;1-9. 
17. Turcato G., L. Panebianco, A. Zaboli, C. Scheurer, D. Ausserhofer, A. Wieser, et al. Correlation between arterial blood gas and CT volumetry in patients with SARS-CoV2 in the emergency department. International Journal of Infectious Diseases. 97: 2020;233-5.

18. Tang N., D. Li, X. Wang, Z. Sun. Abnormal coagulation parameters are associated with poor prognosis in patients with novel coronavirus pneumonia. Journal of thrombosis and haemostasis. 18(4): 2020;844-7.

19. Helms J., C. Tacquard, F. Severac, I. Leonard-Lorant, M. Ohana, X. Delabranche, et al. High risk of thrombosis in patients with severe SARS-CoV-2 infection: a multicenter prospective cohort study. Intensive care medicine. 46(6): 2020;1089-98.

20. Tang N., H. Bai, X. Chen, J. Gong, D. Li, Z. Sun. Anticoagulant treatment is associated with decreased mortality in severe coronavirus disease 2019 patients with coagulopathy. Journal of thrombosis and haemostasis. 18(5): 2020;1094-9.

21. Wynants L., B. Van Calster, G. S. Collins, R. D. Riley, G. Heinze, E. Schuit, et al. Prediction models for diagnosis and prognosis of covid-19: systematic review and critical appraisal. bmj. 369: 2020.

\section{TABLES}


medRxiv preprint doi: https://doi.org/10.1101/2021.11.19.21266581; this version posted November 21, 2021. The copyright holder for this preprint (which was not certified by peer review) is the author/funder, who has granted medRxiv a license to display the preprint in perpetuity.

It is made available under a CC-BY-NC-ND 4.0 International license .

Table 1. Patients demographics and past medical history

\begin{tabular}{|c|c|c|c|}
\hline Characteristic & $\begin{array}{c}\text { Non-intubated } \\
\text { patients } \\
(\mathrm{N}=255)\end{array}$ & $\begin{array}{c}\text { Intubated } \\
\text { patients } \\
(\mathrm{N}=19)\end{array}$ & p-value ${ }^{1}$ \\
\hline Gender, n / N (\%) & & & 0.3 \\
\hline Female & $\begin{array}{l}110 / 255 \\
(43 \%)\end{array}$ & 6 / $19(32 \%)$ & \\
\hline Male & $\begin{array}{l}145 / 255 \\
(57 \%)\end{array}$ & 13 / 19 (68\%) & \\
\hline Age, Median (IQR) & $64(24)$ & $73(15)$ & 0.11 \\
\hline $\begin{array}{l}\text { History of pulmonary disease, } \mathrm{n} / \\
\mathrm{N}(\%)\end{array}$ & & & 0.086 \\
\hline No & $\begin{array}{l}224 / 255 \\
(88 \%)\end{array}$ & $14 / 19(74 \%)$ & \\
\hline Yes & 31 / 255 (12\%) & 5 / $19(26 \%)$ & \\
\hline $\begin{array}{l}\text { Prior anticoagulant therapy, } \mathrm{n} / \mathrm{N} \\
(\%)\end{array}$ & & & 0.010 \\
\hline No & $\begin{array}{l}231 / 255 \\
(91 \%)\end{array}$ & 13 / $19(68 \%)$ & \\
\hline Yes & $\begin{array}{l}24 / 255 \\
(9.4 \%)\end{array}$ & 6 / $19(32 \%)$ & \\
\hline $\begin{array}{l}\text { Days since symptom onset, } \\
\text { Median (IQR) }\end{array}$ & $4.0(6.0)$ & $3.0(6.0)$ & 0.2 \\
\hline $\begin{array}{l}\text { Days until intubation, Median } \\
\text { (IQR) }\end{array}$ & $\mathrm{NA}(\mathrm{NA})$ & $4(6)$ & \\
\hline Unknown & 255 & 0 & \\
\hline NIMV, n / N (\%) & & & $<0.001$ \\
\hline No & $\begin{array}{l}249 / 254 \\
(98 \%)\end{array}$ & 4 / $19(21 \%)$ & \\
\hline Yes & $5 / 254(2.0 \%)$ & $15 / 19(79 \%)$ & \\
\hline Unknown & 1 & 0 & \\
\hline
\end{tabular}


medRxiv preprint doi: https://doi.org/10.1101/2021.11.19.21266581; this version posted November 21, 2021. The copyright holder for this preprint (which was not certified by peer review) is the author/funder, who has granted medRxiv a license to display the preprint in perpetuity.

It is made available under a CC-BY-NC-ND 4.0 International license .

\begin{tabular}{lccc}
\hline Characteristic & $\begin{array}{c}\text { Non-intubated } \\
\text { patients } \\
(\mathrm{N}=255)\end{array}$ & $\begin{array}{c}\text { Intubated } \\
\text { patients } \\
(\mathrm{N}=19)\end{array}$ & p-value $^{1}$ \\
\hline Type of NIMV, $\mathbf{n} / \mathbf{N}(\%)$ & & & \\
\hline BiPAP & $2 / 255(0.8 \%)$ & $4 / 19(21 \%)$ \\
\hline CPAP & $1 / 255(0.4 \%)$ & $2 / 19(11 \%)$ \\
\hline HFNC & $2 / 255(0.8 \%)$ & $9 / 19(47 \%)$ \\
\hline NA & $250 / 255$ & $4 / 19(21 \%)$ \\
\hline
\end{tabular}

Abbreviations: $\mathrm{N}$ : number; pts: patients; IQR: Interquartile range; NIMV: Noninvasive mechanical ventilation; BiPAP: bilevel positive airway pressure machine; CPAP: continuous positive airway pressure machine; HFNC: high flow nasal cannula; NA: not available.

${ }^{1}$ Pearson's Chi-squared test; Wilcoxon rank sum test; Fisher's exact test

Table 2. Values of baseline arterial blood gas analyses.

\begin{tabular}{|c|c|c|c|}
\hline Characteristic & $\begin{array}{c}\text { Non-intubated } \\
\text { patients } \\
(\mathrm{N}=255)\end{array}$ & $\begin{array}{c}\text { Intubated } \\
\text { patients } \\
(\mathrm{N}=19)\end{array}$ & p-value ${ }^{1}$ \\
\hline Baseline pH, Median (IQR) & $7.47(0.05)$ & $7.49(0.06)$ & 0.6 \\
\hline $\begin{array}{l}\text { Baseline } \mathrm{FiO}_{2}(\%) \text {, Median } \\
(\mathrm{IQR})\end{array}$ & $21(11)$ & $44(59)$ & 0.003 \\
\hline $\begin{array}{l}\text { Baseline } \mathrm{HCO}_{3}(\mathrm{mmol} / \mathrm{L}) \text {, } \\
\text { Median (IQR) }\end{array}$ & $25.90(2.90)$ & $23.80(3.62)$ & 0.003 \\
\hline Unknown & 1 & 1 & \\
\hline $\begin{array}{l}\text { Baseline lactate (mmol/L), } \\
\text { Median (IQR) }\end{array}$ & $1.20(0.80)$ & $1.30(0.80)$ & 0.6 \\
\hline Unknown & 2 & 2 & \\
\hline $\begin{array}{l}\text { Baseline } \mathrm{pO}_{2}(\mathrm{mmHg}) \text {, Median } \\
(\mathrm{IQR})\end{array}$ & $86(34)$ & $69(37)$ & 0.020 \\
\hline $\begin{array}{l}\text { Baseline } \mathrm{pCO}_{2}(\mathrm{mmHg}) \text {, } \\
\text { Median (IQR) }\end{array}$ & $33.6(5.7)$ & $29.7(5.0)$ & 0.003 \\
\hline
\end{tabular}


medRxiv preprint doi: https://doi.org/10.1101/2021.11.19.21266581; this version posted November 21, 2021. The copyright holder for this preprint (which was not certified by peer review) is the author/funder, who has granted medRxiv a license to display the preprint in perpetuity.

It is made available under a CC-BY-NC-ND 4.0 International license .

Abbreviations: N: number; pts: patients; IQR: Interquartile range; ph: potential of hydrogern; $\mathrm{FiO}_{2}$ : fraction of inspired oxygen; $\mathrm{HCO}_{3}$ : bicarbonate ion; mmol: millimole; $\mathrm{L}$ : litre; $\mathrm{mmHg}$ : millimetre of mercury; $\mathrm{pO}_{2}$ : partial pressure of oxygen; $\mathrm{pCO}_{2}$ : partial pressure of carbon dioxide. ${ }^{1}$ Wilcoxon rank sum test

Table 3. Results from statistical analysis

\begin{tabular}{|c|c|c|c|c|c|c|}
\hline \multirow[b]{3}{*}{ Characteristic } & \multicolumn{3}{|c|}{ Logistic regression } & \\
\hline & \multicolumn{3}{|c|}{ Univariate } & \multicolumn{3}{|c|}{ Multivariate } \\
\hline & $\mathbf{O R}^{1}$ & $95 \% \mathrm{CI}^{1}$ & p-value & $\mathbf{O R}^{1}$ & $95 \% \mathrm{CI}^{1}$ & p-value \\
\hline \multicolumn{7}{|l|}{ Gender } \\
\hline Female & - & - & & & & \\
\hline Male & 1.64 & $\begin{array}{l}0.63 \\
4.80\end{array}$ & 0.3 & & & \\
\hline Age & 1.03 & $\begin{array}{l}0.99 \\
1.06\end{array}$ & 0.12 & & & \\
\hline \multicolumn{7}{|c|}{$\begin{array}{l}\text { History of } \\
\text { pulmonary disease }\end{array}$} \\
\hline No & - & - & & & & \\
\hline Yes & 2.58 & $\begin{array}{l}0.79 \\
7.28\end{array}$ & 0.088 & & & \\
\hline \multicolumn{7}{|c|}{$\begin{array}{l}\text { Prior anticoagulant } \\
\text { therapy }\end{array}$} \\
\hline No & - & - & & & & \\
\hline Yes & 4.44 & $\begin{array}{l}1.45 \\
12.4\end{array}$ & 0.006 & & & \\
\hline $\begin{array}{l}\text { Days since } \\
\text { symptom onset }\end{array}$ & 0.92 & $\begin{array}{c}0.78 \\
1.05\end{array}$ & 0.2 & 0.86 & $\begin{array}{l}0.71 \\
1.02\end{array}$ & 0.11 \\
\hline \multicolumn{7}{|l|}{ Type of NIMV } \\
\hline BiPAP & - & - & & & & \\
\hline CPAP & 1.00 & 0.05 & $>0.9$ & & & \\
\hline
\end{tabular}


medRxiv preprint doi: https://doi.org/10.1101/2021.11.19.21266581; this version posted November 21, 2021. The copyright holder for this preprint (which was not certified by peer review) is the author/funder, who has granted medRxiv a license to display the preprint in perpetuity.

It is made available under a CC-BY-NC-ND 4.0 International license .

\begin{tabular}{|c|c|c|c|c|c|c|}
\hline \multirow[b]{3}{*}{ Characteristic } & \multicolumn{3}{|c|}{ Logistic regression } & \\
\hline & \multicolumn{3}{|c|}{ Univariate } & \multicolumn{3}{|c|}{ Multivariate } \\
\hline & $\mathbf{O R}^{1}$ & $95 \% \mathrm{CI}^{1}$ & p-value & $\mathbf{O} \mathbf{R}^{1}$ & $95 \% \mathrm{CI}^{1}$ & p-value \\
\hline \multicolumn{7}{|c|}{29.8} \\
\hline HFNC & 2.25 & $\begin{array}{l}0.21 \\
25.2\end{array}$ & 0.5 & & & \\
\hline NA & 0.01 & $\begin{array}{l}0.00 \\
0.05\end{array}$ & $<0.001$ & & & \\
\hline Baseline FiO2 (\%) & 1.05 & $\begin{array}{l}1.03 \\
1.07\end{array}$ & $<0.001$ & 1.05 & $\begin{array}{l}1.03 \\
1.08\end{array}$ & $<0.001$ \\
\hline $\begin{array}{l}\text { Baseline pCO2 } \\
(\mathrm{mmHg})\end{array}$ & 0.86 & $\begin{array}{l}0.76 \\
0.97\end{array}$ & 0.014 & 0.84 & $\begin{array}{l}0.73 \\
0.95\end{array}$ & 0.008 \\
\hline Last FiO2 (\%) & 1.21 & $\begin{array}{l}1.11 \\
1.46\end{array}$ & 0.004 & & & \\
\hline Last pCO2 (mmHg) & 1.08 & $\begin{array}{l}1.01 \\
1.16\end{array}$ & 0.019 & & & \\
\hline $\begin{array}{l}\text { Total severity } \\
\text { score (TSS) }\end{array}$ & 1.18 & $\begin{array}{l}1.03 \\
1.37\end{array}$ & 0.018 & & & \\
\hline $\begin{array}{l}\text { Baseline pO2 } \\
\text { (mmHg) }\end{array}$ & 0.98 & $\begin{array}{l}0.96 \\
1.00\end{array}$ & 0.075 & & & \\
\hline Last pO2 (mmHg) & 0.89 & $\begin{array}{l}0.85 \\
0.92\end{array}$ & $<0.001$ & & & \\
\hline $\begin{array}{l}\text { Time elapsed from } \\
\text { symptoms to first } \\
\text { ABGs }\end{array}$ & 0.95 & $\begin{array}{l}0.89 \\
0.99\end{array}$ & 0.2 & & & \\
\hline OR = Odds Ratio, $\mathrm{CI}=$ & nfide & e Interval & & & & \\
\hline
\end{tabular}

Abbreviations: NIMV: Non-invasive mechanical ventilation; BiPAP: bilevel positive airway pressure machine; CPAP: continuous positive airway pressure machine; HFNC: high flow nasal cannula; NA: not available; $\mathrm{FiO}_{2}$ : fraction of inspired oxygen; $\mathrm{pCO}_{2}$ : partial pressure of carbon dioxide; $\mathrm{pO}_{2}$ : partial pressure of oxygen; $\mathrm{ABG}$ : arterial blood gases. 
medRxiv preprint doi: https://doi.org/10.1101/2021.11.19.21266581; this version posted November 21, 2021. The copyright holder for this preprint (which was not certified by peer review) is the author/funder, who has granted medRxiv a license to display the preprint in perpetuity.

It is made available under a CC-BY-NC-ND 4.0 International license . 
medRxiv preprint doi: https://doi.org/10.1101/2021.11.19.21266581; this version posted November 21, 2021. The copyright holder for this preprint (which was not certified by peer review) is the author/funder, who has granted medRxiv a license to display the preprint in perpetuity.

It is made available under a CC-BY-NC-ND 4.0 International license .

All patients hospitalized with COVID-19 in our center

Patients included for the composite outcome

Patients included in the study

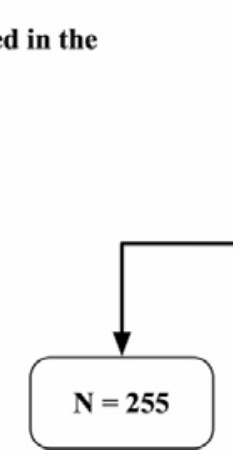

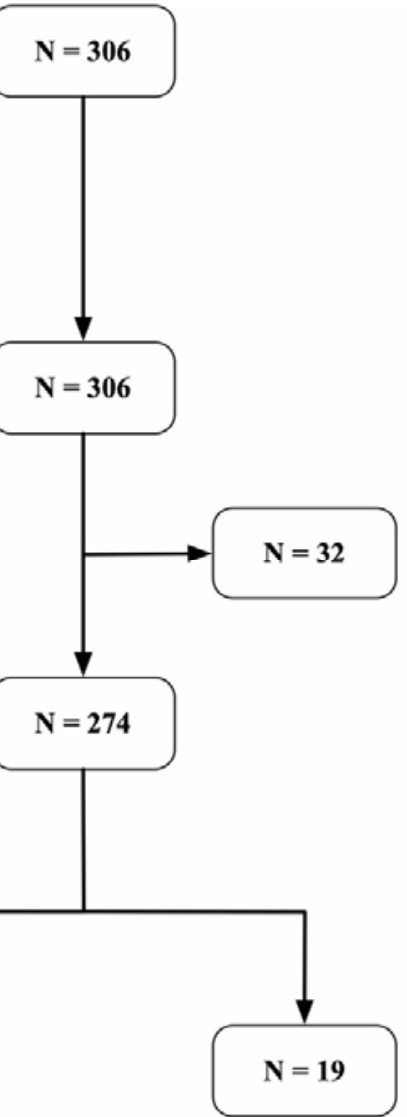

Non-intubated COVID-19 patients who died (palliative care or irrelevant to COVID-19 cause of death)
Intubated

patients 